Florida International University

FIU Digital Commons

FCE LTER Journal Articles

FCE LTER

2006

\title{
Assessing the net effect of anthropogenic disturbance on aquatic communities in wetlands: community structure relative to distance from canals
}

Jennifer S. Rehage

Department of Biological Sciences, Florida International University, rehagej@fiu.edu

Joel C. Trexler

Department of Biological Sciences, Florida International University, trexlerj@fiu.edu

Follow this and additional works at: https://digitalcommons.fiu.edu/fce_lter_journal_articles

\section{Recommended Citation}

Rehage, J.S., J.C. Trexler. 2006. Assessing the net effect of anthropogenic disturbance on aquatic communities in wetlands: Community structure relative to distance from canals. Hydrobiologia 569(1):359-373.

This material is based upon work supported by the National Science Foundation through the Florida Coastal Everglades Long-Term Ecological Research program under Cooperative Agreements \#DBI-0620409 and \#DEB-9910514. Any opinions, findings, conclusions, or recommendations expressed in the material are those of the author(s) and do not necessarily reflect the views of the National Science Foundation. This work is brought to you for free and open access by the FCE LTER at FIU Digital Commons. It has been accepted for inclusion in FCE LTER Journal Articles by an authorized administrator of FIU Digital Commons. For more information, please contact dcc@fiu.edu, jkrefft@fiu.edu. 
1 Running Head: Effects of canals on wetland aquatic animal communities

2

3

4 Assessing the Net Effect of Anthropogenic Disturbance on Aquatic Communities in Wetlands: 5

6

19 This paper has not been submitted elsewhere in identical or similar form, nor will it be during the

20 first three months after its submission to Hydrobiologia.

21

22 Last Revised: November 30, 2005

23 Key words: wetlands, canals, anthropogenic disturbance, density, community structure 


\section{Abstract}

2 Anthropogenic alterations of natural hydrology are common in wetlands and often

3 increase water permanence, converting ephemeral habitats into permanent ones. Since aquatic

4 organisms segregate strongly along hydroperiod gradients, added water permanence caused by

5 canals can dramatically change the structure of aquatic communities. We examined the impact

6 of canals on the abundance and structure of wetland communities in South Florida, U.S.A. We

7 sampled fishes and macroinvertebrates from marsh transects originating at canals in the central

8 and southern Everglades. Density of all aquatic organisms sampled increased in the immediate

9 proximity of canals, but was accompanied by few compositional changes based on analysis of

10 relative abundance. Large fish $(>8 \mathrm{~cm})$, small fish $(<8 \mathrm{~cm})$, and macroinvertebrates $(>5 \mathrm{~mm})$

11 increased in density within $5 \mathrm{~m}$ of canals. This pattern was most pronounced in the dry season,

12 suggesting that canals may serve as dry-down refugia. Increases in aquatic animal density

13 closely matched gradients of phosphorus enrichment that decreased with distance from canals.

14 Thus, the most apparent impact of canals on adjacent marsh communities was as conduits for

15 nutrients that stimulated local productivity; any impact of their role as sources of increased

16 sources of predators was not apparent. The effect of predation close to canals was

17 overcompensated by increased secondary productivity and/or immigration toward areas adjacent

18 to canals in the dry season. Alternatively, the consumptive effect of predatory fishes using

19 canals as dry-season refuges is very small or spread over the expanse of marshes with open

20 access to canals. 


\section{Introduction}

Anthropogenic activities have altered freshwater ecosystems worldwide, severely

3 threatening their ecological integrity (NCR, 1992; Naiman \& Turner, 2000). The addition of

4 dams, impoundments, channels, canals, and levees has dramatically disrupted flow, flooding

5 cycles, and hydrologic connectivity (Dynesius \& Nilsson, 1994; Power et al. 1995; Rosenberg et

6 al. 2000; Pringle, 2001; Brönmark \& Hansson, 2002). In temporary habitats, anthropogenic

7 hydrologic alterations often result in changes in the amount, extent, and timing of flooding

8 (Bedford \& Preston, 1988). In many cases, drainage and impoundment results in complete loss

9 of wetlands or temporary ponds (Turner et al. 1998). In other instances, hydrologic alterations

10 may increase water permanence, converting ephemeral habitats into permanent ones (Gergel,

11 2002). Aquatic organisms have been shown to segregate strongly along gradients of aquatic

12 habitat permanence (Wilbur, 1980; Schneider \& Frost, 1996; Wellborn et al. 1996; Corti et al.

13 1997; Skelly et al. 1999). Large predatory fish are typically absent from temporary wetlands,

14 providing a predation refuge for many small aquatic organisms. Thus, lengthening hydroperiod

15 and enhancing habitat connectance may result in marked changes in community structure and

16 ecosystem function.

17 In the Florida Everglades, drainage and impoundment have drastically altered hydrologic

18 conditions and reduced the extent of shallow, seasonal wetlands by more than $40 \%$ (Davis et al.

19 1994). Presently, over $1,600 \mathrm{~km}$ of canals and $1,150 \mathrm{~km}$ of levees compartmentalize the system

20 and disrupt the natural southerly sheet flow of water over vegetated marshes (Light \& Dineen,

21 1994). Historically, the spatial extent of marsh inundation (and thus habitat for aquatic

22 organisms) fluctuated seasonally in response to rainfall patterns (high in the summer and fall,

23 low in the winter and spring). Today, inundation and flow are largely controlled by this 
1 extensive system of water control structures, levees, and canals. Beyond altering flow and

2 hydroperiod, canals provide permanent deep-water refuges for biota that were historically rare or

3 absent in the ecosystem (Gunderson \& Loftus, 1993). These artificial habitats harbor relatively

4 high numbers of predatory and non-indigenous fishes (Loftus \& Kushlan, 1987; Trexler et al.

5 2001) that may alter the small fish and macroinvertebrate communities of nearby marshes.

6 Alterations to the natural hydrologic regime of wetlands are often accompanied by

7 alterations in nutrient inputs (Sanchez-Carrillo \& Alvarez-Cobelas, 2001). The Everglades is an

8 oligotrophic wetland, which historically received most of its nutrients from rain. Like many

9 freshwater wetlands, Everglades marshes are phosphorus (P)-limited (McCormick et al. 1996).

10 Ambient concentrations of total phosphorus (TP) in the water column are typically below 10

$11 \mu \mathrm{g} / \mathrm{L}$ (Davis, 1994). Over the past decades, however, the ecosystem has been subjected to

12 anthropogenic P enrichment. Discharge from canals bordering northern agricultural lands is the

13 main source of nutrients; TP concentration in canal runoff has been as high as 30-times ambient

14 levels (McCormick et al. 1996). A number of alterations to the structure and function of the

15 Everglades ecosystem have resulted from P enrichment, even at very low levels (Davis, 1994;

16 Doren et al. 1997; Noe et al. 2001; Gaiser et al. 2005). Among these impacts, fish and

17 macroinvertebrate biomass and density have been shown to increase at high TP concentrations

18 (Rader \& Richarson, 1994; Turner et al. 1999; Gaiser et al. 2005).

19 The impact of canals on aquatic organisms inhabiting Everglades wetlands may depend

20 on the relative strength of predation and nutrient enrichment. If canals provide key habitats for

21 predatory fish species, predation pressure may increase in nearby marshes. On the other hand, if

22 canals act as a source of nutrients, prey species may increase as the enrichment effect is

23 transmitted up the food web. When both resource stimulation and enhanced predatory 
1 consumption combine, there may be no net effect or a dampening of the stronger factor by the

2 weaker one. The overall effect may be complex in systems such as the Everglades where

3 omnivory is widespread (Leibold et al. 1997; Polis \& Strong, 1996).

4 In this study, we examined patterns of fish and macroinvertebrate communities relative to 5 distance from canals to evaluate the net effect of nutrients and predation. We asked: (1) How do

6 fish and macroinvertebrate communities change with proximity to canals? (2) Over what

7 distance do canals influence aquatic communities? and (3) Does the effect vary between

8 undisturbed and disturbed marshes (in this case, marshes impacted by airboat traffic)? To

9 address these questions, we sampled large fishes, small fishes, and macroinvertebrates in

10 transects originating at canals and extending into un-channelized marshes. We were particularly

11 interested in determining the effect of proximity to canals on the small fish assemblage, which

12 dominates fish standing crops and abundance (Turner et al. 1999; Trexler et al. 2002) and

13 constitutes an important food source for wading birds (Frederick \& Spalding, 1994). We focused

14 on the effect of canals at small spatial scales (5 to $1000 \mathrm{~m}$ ), because our study sites consisted of

15 canals with relatively low nutrient enrichment compared to some of the canals included in

16 previous studies (e.g., Doren et al. 1997; Childers et al. 2003). By avoiding canals with high

17 nutrient enrichment and extensive areas of nutrient-enriched marsh downstream, we increased

18 the possibility of documenting the role of canals as a predator source, if present.

\section{Methods}

21 We sampled fish and macroinvertebrates in transects originating at 5 canals: 775 , L28,

22 L29 and L67 in Water Conservation Area 3A (WCA3A) and the C111 in the southern

23 Everglades, Florida, USA (Fig. 1). These canals are located in the central and southern regions 
1 of the Everglades, far south of the primary sources of P loading to the ecosystem. These

2 transects spanned marshes of varying hydroperiod; those in the proximity of the $\mathrm{C} 111$ had the

3 shortest hydroperiod (174 - 364 days from 1996 - 2001), those in the proximity of the L28 and

$4 \quad$ I75 had intermediate hydroperiods (225 - 365 days from 1996 - 2001), and those in the proximity

5 of the L29 and L67 exhibited the longest hydroperiod (327 - 365 days from 1996 - 2001).

6 Two transects were established at each of our canal sites, one that followed an airboat

7 trail and a parallel transect in the surrounding undisturbed marsh (approximately $350 \mathrm{~m}$ apart).

8 Sampling was conducted at 5, 100, 500, and $1000 \mathrm{~m}$ along each transect. For the marsh transect,

9 a fifth site was included at an average distance of $7500 \mathrm{~m}$ from canals. In the central region of

10 WCA3A, these sites were at $3200 \mathrm{~m}$ from the $\mathrm{I75}, 4400 \mathrm{~m}$ from the $\mathrm{L} 28,6600 \mathrm{~m}$ from the $\mathrm{L} 67$,

11 and $11400 \mathrm{~m}$ from the $\mathrm{L} 29$ canals respectively. For the $\mathrm{C} 111$ canal, the inner site was located at

$1211900 \mathrm{~m}$ from the canal in the Madeira ditches region of Taylor Slough (Fig. 1). Transects

13 bisected Eleocharis spp-dominated wet prairies in WCA3A and Cladium jamaicense-dominated

14 marl prairies in the $\mathrm{C} 111$ area. Sampling sites along the 2 transects had similar macrophytes

15 densities (Marsh: $184 \pm 31$ stems m${ }^{-2}$; Trail: $203 \pm 32$ stems m$^{-2}$; ANOVA: $\mathrm{F}_{1,130}=1.3, \mathrm{p}=$

16 0.27), but differed in periphyton cover (Marsh: $2783 \pm 229 \mathrm{ml} \mathrm{m}^{-2}$; Trail: $2260 \pm 260 \mathrm{ml} \mathrm{m}^{-2}$;

17 ANOVA: $\mathrm{F}_{1,131}=12.4, \mathrm{p}=0.0006$ ). We sampled in both the wet (September 2003) and dry

18 seasons (January and March 2003). Water depth at our sampling sites averaged $72 \pm 1.9 \mathrm{~cm}$

19 during the wet season and $48 \pm 2.0 \mathrm{~cm}$ during the dry season sampling event.

20 Small fish (standard length $(\mathrm{SL})<8 \mathrm{~cm}$ ) and macroinvertebrates (maximum dimension $>$

$215 \mathrm{~mm}$ ) were sampled with a $1-\mathrm{m}^{2}$ throw trap with 2-mm mesh netting on the sides, which were

22 cleared from the trap using standardized techniques (Kushlan, 1981; Jordan et al. 1997). Before

23 clearing the trap, we quantified the number of emergent stems and the volume of floating 
1 periphyton. All animals were preserved in $10 \%$ formalin in the field and brought to the

2 laboratory for identification and enumeration. Three throw-trap samples were taken at each

3 distance within each transect $(3$ throws $\times 4$ distances $\times 2$ transects $\times 5$ canal sites $\times 2$ seasons $=$

4240 throws +30 throws at the $7500 \mathrm{~m}$ marsh site $=270$ possible throws). Actual sample size

5 was 258 because half of the sites at the $\mathrm{C} 111$ canal were dry at the time of the dry-season

6 sampling in early January 2003.

7 Large fish $(\mathrm{SL}>8 \mathrm{~cm}$ ) were sampled using an airboat-mounted electrofishing unit (two-

8 anode one-cathode apparatus with a Smith-Root ${ }^{\circledR}$ GPP 9.0 control box). Electrofishing has been

9 shown to be an effective method for sampling large fishes in marshes, and electrofishing catch

10 per unit effort (CPUE) provides a reliable index of fish abundance (Chick et al. 1999). Sampling

11 was conducted in 25 -minute bouts (pedal time) at each distance within each transect ( 2 bouts $\mathrm{x} 4$

12 distances $\times 2$ transects $\times 5$ canal sites $\times 2$ seasons $=160$ bouts +20 bouts at $7500 \mathrm{~m}$ mash site $=$

13180 possible bouts). For all bouts, electrofishing power was standardized at 1500 watts

14 according to temperature and conductivity conditions (Chick et al. 1999). All fish captured were

15 identified to species, measured to nearest $1 \mathrm{~mm} \mathrm{SL}$, and released after full recovery. Final

16 sample size was 162 bouts because most of the C111 sites were dry at the time of the dry season

17 sampling and we were unable to sample the L28 $7500 \mathrm{~m}$ marsh site.

18 To investigate the presence of a nutrient enrichment gradient as a function of distance

19 from canals, we measured TP concentrations in the flocculent detrital organic layer (floc) above

20 the soil. The floc layer is the most microbiologically active layer of Everglades soils and plays a

21 key role in short-term uptake and cycling of $\mathrm{P}$ (Noe et al. 2002). Because of its high

22 responsiveness to nutrient inputs, the floc layer may be more closely tied to food web responses

23 to enrichment. We collected floc samples with a $2.4-\mathrm{cm}$ diameter coring device. Three cores 
1 were collected from a $1-\mathrm{m}^{2}$ area and combined into a composite sample (Noe et al. 2002). Three

2 composite samples were taken at each sampling location (3 composite samples $\mathrm{x} 4$ distances $\mathrm{x} 2$

3 transects $\mathrm{x} 5$ canal sites $=120+15$ samples at $7500 \mathrm{~m}$ marsh site $=135$ possible samples).

4 Samples were dried at $70^{\circ} \mathrm{C}$ for 48 hours, crushed to a fine powder, and analyzed for $\mathrm{TP}$ in a

5 spectrophotometer following standardized procedures (Fourqurean et al. 1992). All samples were

6 collected in March 2004, except for the 7500 m samples, which were collected in October 2002.

7 At the C111 canal, floc samples were only obtained at the $5 \mathrm{~m}$ and $7500 \mathrm{~m}$ distances; thus final

8 sample size was 117 samples.

\section{Statistical analyses}

11 We examined variation in the abundance of fish and macroinvertebrates among canal

12 sites and as a function of season, distance from canals, and disturbance level (marsh vs. trail

13 transects) with nested, repeated-measures ANOVA models. Season was the repeated measure in 14 our analyses, and nesting allowed us to account for spatial variation among our canal sites. We

15 tested for the effect of distance nested within canal site, and for the effect of disturbance nested

16 within distance and canal. Focal response variables included: TP concentration $\left(\mu \mathrm{g} \mathrm{g}{ }^{-1}\right), \mathrm{CPUE}$

17 of large fishes (number $5 \mathrm{~min}^{-1}$ electrofishing bout), and densities of small fish and

18 macroinvertebrates (number $\mathrm{m}^{-2}$ ). Stem density (number $\mathrm{m}^{-2}$ ) and periphyton volume $\left(\mathrm{ml} \mathrm{m}^{-2}\right.$ )

19 were used as covariates in analyses of the throw-trap data. In order to better satisfy assumptions

20 of parametric tests, all variables were $\ln ($ observed value +1$)$-transformed prior to analyses. Post

21 hoc pairwise comparisons were performed using Tukey-corrected contrasts. Some pairwise

22 comparisons involving the C111 sites could not be conducted because of missing dry season

23 data. Simple linear regressions were used to examine the relationship between TP and estimates 
1 of abundance. All analyses were performed using SAS Version 9.1.3®. ANOVAs were

2 performed using Proc MIXED using compound symmetric covariance structures in the repeated

3 measures (Littell et al. 1996).

4 We used one-way analysis of similarity (ANOSIM) based on Bray-Curtis dissimilarity

5 matrices to test for effects of canal site, distance, and disturbance on fish and macroinvertebrate

6 community structure (Clarke \& Warwick, 2001). Dissimilarity matrices were constructed

7 separately for the large fish, small fish, and macroinvertebrate communities based on square-root

8 transformed estimates of the relative abundance of taxa averaged across seasons; no seasonal

9 variation was evident in preliminary analyses. Analyses included 22 large fish species, 28 small

10 fish species, and 36 macroinvertebrate taxa. We identified macroinvertebrates to the lowest

11 practical taxonomic resolution, which included 26 species, 2 genera, 4 families, 2 orders, and 2

12 classes (Table 1). ANOSIM tests produce Global R statistics with values ranging between 1 and

$13-1$. Values closer to 1 indicate greater community dissimilarity among groups than within, while

14 values closer to -1 indicate less dissimilarity among groups than within. We followed ANOSIM

15 analyses with similarities percentage breakdown analyses (SIMPER) to determine which taxa

16 were contributing most to groupings observed among samples. Once key taxa were identified,

17 we examined the magnitude of variation in abundance with one-way ANOVAs, followed by

18 Tukey post hoc comparisons. We then constructed non-metric multi-dimensional scaling (MDS)

19 plots to illustrate dissimilarity among groups. All community structure analyses were conducted 20 using Primer@ Version 5.2.9. 


\section{$1 \quad$ Results}

\section{Small fish density}

3 Densities of small fishes varied among canal study sites, and this variation differed

4 between sampling seasons (Table 1). On average, small fishes were least abundant in the

5 proximity of the L29 canal and most abundant in marshes bordering the C111, I75, and L28

6 canals (9 vs. 34 fish $\mathrm{m}^{-2}$ ) (Tukey pairwise comparisons, all $\left.p=0.0001\right)$. Overall, densities

7 increased between the wet and dry season ( $21 \mathrm{vs.} 31$ fish $\mathrm{m}^{-2}$ ), but there was large variation in the

8 magnitude and direction of this seasonal effect among canals. Compared to the wet season data,

9 small fish density increased by $200 \%$ in the C111, $100 \%$ in the L28, and $40 \%$ in the L29 canal

10 in the dry season $(p<0.08)$. In contrast, density decreased by $50 \%$ in the L67 canal $(p=0.009)$

11 and remained unchanged at the $\mathrm{I75}$ site. Density also varied as a function of distance from

12 canals, and this effect was greatest in the dry season and canal-specific (Fig. 2a). In the wet

13 season, a distance effect was only detected at the C111 site; there was a 10 -fold increase in

14 density within $5 \mathrm{~m}$ of the canal compared to $100-1000 \mathrm{~m}$ distances $(p<0.04)$. In the dry

15 season, density increased significantly within $5 \mathrm{~m}$ of canals in marshes adjacent to the $\mathrm{I75}$ and

16 C111 canals $(p<0.04)$ and to a lesser extent in the L29 canal $(5 \mathrm{~m} \mathrm{vs} .500 \mathrm{~m}, p=0.06)$. This

17 effect was localized to the immediate vicinity of canals; small-fish density at $100 \mathrm{~m}$ of canals

18 was remarkably similar to those at greater distances. In the L29 canal, densities significantly

19 increased at $100 \mathrm{~m}$, but not $5 \mathrm{~m}(100 \mathrm{~m}$ vs. $500, p=0.002)$. The L67 site was the only canal

20 where dry-season density did not vary as a function of distance from the canal (Fig. 2a). Few

21 effects of anthropogenic disturbance on small-fish density were detected. Differences between

22 the airboat trail and adjacent undisturbed marsh were only detected in the I75 and L28 canals and

23 only at 3 of the 10 distances sampled. In all three instances, density was higher in the airboat 
1 trail $(p<0.08 ; 50$ to $500 \%$ difference). Small-fish density was positively correlated to emergent

2 macrophyte stem density, but negatively correlated to periphyton volume (Table 1).

$4 \quad$ Macroinvertebrate density

5 Similar to the small fish, macroinvertebrate density varied among canal sites, with the

6 lowest densities in the immediate proximity of the L29 canal $(p<0.04)$. Overall, density varied

7 with season, and more than tripled in the dry season compared to the wet season (20 vs. 69

8 macroinvertebrates $\mathrm{m}^{-2}$ ). However, the magnitude of the seasonal effect was canal-specific

9 (Table 1); density increased in the dry season in the C111, L28 and L29 canals $(p<0.003)$, but

10 remained the same in the I75 and L67 canals. Density of macroinvertebrates varied markedly

11 with distance from a canal. Most of the distance variation was observed in the dry season, and as

12 seen in the small fish data it was particularly evident between the $5 \mathrm{~m}$ and all greater distances

13 (Fig. 2b). Only in the L67 canal did density vary as a function of distance during the wet season.

14 Density within $5 \mathrm{~m}$ of the L67 canal was 5 times higher than at greater distances $(p<0.005$,

15 except for 5 vs. $500 \mathrm{~m}, p=0.85$ ). At four canal transects, C111, I75, L67 and L28, dry-season

16 macroinvertebrate density was 8 times higher within $5 \mathrm{~m}$ of the canal than at greater distances $(p$

17 <.05). No distance effect was detected at the L29 canal transects. Disturbance affected

18 macroinvertebrate density only in the proximity of canals and only in a subset of sites,

19 particularly the I75 and L28 canals. At $5 \mathrm{~m}$, density was higher in the airboat trail than the

20 undisturbed marsh $(\mathrm{I} 75, p=0.0001 ; \mathrm{L} 28, p=0.005)$. Macroinvertebrate density in our samples

21 was positively related to emergent macrophyte stem density, but unrelated to periphyton volume

22 (Table 1). 
Differences among canals in electrofishing CPUE varied between seasons (Table 1).

3 Overall, CPUE increased sharply at all sites in the dry season, from an average of 2 in the wet

4 season to 21 fish bout $^{-1}$. In the wet season, CPUE was highest in the L67 canal and lowest in the

5 C111 canal $(p=0.005)$. In the dry season, only the L29 and I75 canals differed (17 vs. 11 fish

6 bout $^{-1}, p=0.0002$ ). A gradient in CPUE as a function of distance was only detected in the dry

7 season, but the effect was consistent for the 4 canals sampled fully (no data at distances greater

8 than $5 \mathrm{~m}$ were available for the $\mathrm{C} 111$ canal) (Fig. 2c). The most striking effect was the increase

9 in CPUE within $5 \mathrm{~m}$ detected in the $\mathrm{I75}$ and L28 canals ( 5 vs. other distances, all $p<0.01$ ).

10 CPUE averaged 3 and 7 fish bout $^{-1}$ at 100-7500 $\mathrm{m}$ in the I75 and L28 canals respectively, but

11 increased to 39 and 186 fish bout $^{-1}$ within $5 \mathrm{~m}$ of canals. In the L29 canal, the effect of the canal

12 was seen as far as $1000 \mathrm{~m}$ away. Dry season CPUE averaged 19 fish in the 5-1000 m range, but

13 was only 2 fish bout ${ }^{-1}$ at the inner-marsh site $(p<0.04)$. Less variation in CPUE was detected at

14 the L67-canal transect, although variation was in the same direction; catches were higher close to

15 the canal (5 vs. $1000 \mathrm{~m}, p=0.02$ ). Disturbance only affected CPUE in the L28 canal, and the

16 effect was only detected at $5 \mathrm{~m}$; CPUE at $5 \mathrm{~m}$ averaged 147 fish bout $^{-1}$ in the airboat trail, but

17 only 43 fish bout ${ }^{-1}$ in the undisturbed marsh $(p=0.06)$.

19 Nutrient gradient

20 Floc TP concentration varied significantly among canal sites (Fig. 3). Mean

21 concentration was highest in marshes along the $\mathrm{L} 28$ canal $\left(1113.4 \mu \mathrm{g} \mathrm{g}^{-1}\right)$, intermediate for the

22 L29, L67, and I75 canal sites $\left(816.1 \mu \mathrm{g} \mathrm{g}^{-1}\right)$ and lowest along the C111 canal $\left(412.4 \mu \mathrm{g} \mathrm{g}^{-1}\right)(p<$

23 0.05). Concentrations varied as a function of distance in all canal sites (Table 1) except the 
1 C111, although only two distances were available for this canal (5 vs. $7500 \mathrm{~m}, p=1.000)$. In the

2 other four sites, concentrations increased by $50 \%$ within $5 \mathrm{~m}$ of canals (5 vs. all other distances,

$3 p<0.006)$. Interestingly, concentrations at $7500 \mathrm{~m}$ were very similar to concentrations in the

$4 \quad 100-1000 \mathrm{~m}$ range. The only exception was the L28 canal, where concentrations at $100 \mathrm{~m}$

5 doubled concentrations found at the inner-marsh site $(p=0.004)$. Disturbance from airboat

6 traffic had little effect on TP concentrations; in 4 out of the 5 canals, pairwise comparisons at

7 each distance showed no differences in TP between the airboat trail and the undisturbed marsh.

8 The L28 canal was the exception; on average, concentrations in the airboat trail doubled those of

9 the marsh transect (marsh vs. trail differed for all distances at $p=0.0001$; except for $100 \mathrm{~m}, p=$

10 1.000). The abundances of all organisms, averaged across seasons, were positively correlated

11 with TP concentrations across study sites (Large fish, $\mathrm{R}^{2}=0.37, p=0.0001$; small fish, $\mathrm{R}^{2}=$

$120.15, p=0.016$; macroinvertebrates: $\mathrm{R}^{2}=0.23, p=0.002$ ) (Fig. 4).

14 Community structure variation among canals

15 Community structure varied consistently among canal sites (Small fishes: Global $\mathrm{R}=$

$160.49, p=0.001$; macroinvertebrates: Global $\mathrm{R}=0.32, p=0.001$; large fishes: Global $\mathrm{R}=0.22, p$

$17=0.001$ ). The greatest difference among canals was detected in the small-fish community (Fig.

18 5a). Small-fish community structure in the L29 canal was distinct from that of the C111, I75,

19 and L28 (Pairwise comparisons: R $>0.75, p<0.002$ ). Density of eastern mosquitofish

20 (Gambusia holbrooki), least killifish (Heterandria formosa), and golden topminnow (Fundulus

21 chrysotus) were lowest in the L29 canal relative to other canals (Tukey pairwise comparisons: all

$22 p<0.05$ ). Bluespotted sunfish (Enneacanthus gloriosus) were found at their highest densities at

23 the L29 and L67 canal transects, while flagfish (Jordanella floridae) were found at their lowest 
1 densities there $(p<0.03)$. Marsh killifish (Fundulus confluentus) were most abundant at the

2 C111 canal $(p=0.0001)$. The other large canal difference was between the I75 and L67 canals

$3 \quad(\mathrm{R}=0.76, p=0.001)$. The I75 canal sites had higher densities of flagfish and least killifish and

4 lower densities of bluespotted sunfish compared to the L67 canal sites $(p<0.02)$.

5 Community structure of macroinvertebrates also varied between the L29 and the I75,

6 L28, and C111 canals (Pairwise R > 0.46, $p<0.002$ ) and to a similar degree between the L28

7 and L67 canals $(\mathrm{R}=0.49, \mathrm{p}=0.001)$. Everglades crayfish (Procambarus alleni), slough crayfish

8 (Procambarus fallax), creeping water bugs (Pelocoris femoratus), halloween pennant dragonfly

9 naiads (Celithemis eponina), four-spotted pennant dragonfly naiads (Brachymesia gravida), and

10 aquatic beetles (adult Coleoptera) were responsible for over $50 \%$ of the dissimilarity among

11 these canals. Everglades crayfish were found almost exclusively in marshes adjacent to the

12 C111 canal, whereas slough crayfish were most dense at the I75 and L28 canal sites, and less

13 dense in the L67 canal $(p<0.02)$. Among dragonflies, halloween pennant naiads were the most

14 common dragonfly species at the L29, whereas four-spotted pennants were most common at the

15 L67 canal; both species were found at low densities at the L28 canal transect $(p=0.05$ and $p=$

160.001 respectively). Beetles and creeping water bugs were most dense at the C111 and L29

17 canal transects $(p<0.03)$.

18 The greatest inter-canal differences in large-fish community structure were observed

19 between the $\mathrm{C} 111$ and $\mathrm{L} 29$ and $\mathrm{L} 67$ canals (Global $\mathrm{R}=0.56, p=0.009$, and Global $\mathrm{R}=0.55, p=$

200.02 respectively). Lake chubsuckers (Erymizon sucetta) were more common at the L29 canal

21 than the C111 canal, whereas blue tilapia (Oreochromis aureus) and Seminole killifish

22 (Fundulus seminolis), although caught in low numbers (Appendix 1), were almost exclusively

23 found at the $\mathrm{C} 111$ canal area $(p<0.027)$. 
Distance from a canal had little effect on community structure of small fishes (Global $\mathrm{R}=$

$3-0.04, p=0.84$ ) and macroinvertebrates (Global $\mathrm{R}=0.04, p=0.148$ ), but did impact structure of

4 large fish communities (Global $\mathrm{R}=0.23, p=0.001$ ). As seen in the density analyses,

5 community variation was only seen in the immediate proximity of canals. Structure at $5 \mathrm{~m}$

6 differed markedly from all other distances $(p<0.003)$ and dissimilarity was greatest between the

$75 \mathrm{~m}$ and the inner $7500 \mathrm{~m}$ sites (highest $\mathrm{R}=0.79, p=0.003$ ) (Fig 5c). Eight species accounted

8 for about $70 \%$ of the dissimilarity between $5 \mathrm{~m}$ and other distances: Florida gar (Lepisosteus

9 platyrhincus), largemouth bass (Micropterus salmoides), warmouth (Lepomis gulosus), redear

10 sunfish (Lepomis microlophus), bluegill sunfish (Lepomis macrochirus), spotted sunfish

11 (Lepomis punctatus), lake chubsucker, and bowfin (Amia calva). Density varied as a function of

12 distance for a subset of these species. Florida gar, largemouth bass, redear sunfish, and bluegill

13 were more common within 5 m of canals ( 5 vs. 7500 , all $p<0.05$ ).

\section{Community structure as a function of disturbance}

16 We observed little effect of disturbance on the structure of the aquatic community in our

17 study sites. Fish community structure did not differ between the undisturbed marsh transect and

18 the airboat trail (Large fishes: Global $\mathrm{R}=0.01, p=0.38$; small fishes: Global $\mathrm{R}=0.02, p=$

19 0.21). Macroinvertebrates did vary between airboat trails and adjacent marsh, although the

20 difference was not marked (Global $\mathrm{R}=0.10, p=0.001)$. Differences in density between the two

21 transect types were detected in only 3 of the 36 macroinvertebrate taxa. Creeping water bug

22 density was higher in undisturbed marsh $\left(F_{1,43}=12.2, p=0.001\right)$, whereas density of riverine

23 grass shrimp (Palaemonetes paludosus) and four-spotted pennant naiads tended to be higher in 
1 airboat trails than the adjacent marsh $\left(F_{1,43}=3.0, p=0.09\right.$, and $F_{1,43}=3.8, p=0.07$

2 respectively).

4 Discussion

Water control structures, levees, and canals have become ubiquitous features in aquatic

6 ecosystems. In many cases, these may not be practically removed because of present-day

7 requirements for flood control in human-dominated landscapes, even in systems undergoing

8 restoration. In the Everglades, restoration efforts call for the removal of only 380 of the more

9 than $2500 \mathrm{~km}$ of canals and levees that presently control the amount, extent, and timing of water

10 delivery (CERP, 1999). Understanding how these man-made features affect the structure of

11 aquatic communities and key ecosystem processes is a critical component of understanding the

12 ecology of this ecosystem. Our sampling found evidence of an effect of man-made canals on the

13 abundance of aquatic organisms inhabiting nearby marshes, but little effect on their community

14 structure. In contrast, previous studies conducted in the northern Everglades have documented

15 changes in community structure with distance from canals in both vegetation (King et al. 2004)

16 and macroinvertebrate communities (McCormick et al. 2004). In our study, distance from a canal

17 consistently affected patterns of abundance in the macroinvertebrate, small fish, and large fish

18 communities, but only over short distances. In all three cases, density increased within the

19 immediate proximity of canals $(5 \mathrm{~m})$, while communities at $100 \mathrm{~m}$ or greater distances were

20 remarkably similar to those found in interior marshes.

21 The increases in the density of all aquatic groups (both small prey and large predatory

22 species) in marshes adjacent to canals matches the spatial pattern of $\mathrm{P}$ enrichment, suggesting a

23 role for resource stimulation provided by canals. Floc TP increased sharply within $5 \mathrm{~m}$ of canals 
1 in all cases except the southern-most canal, the C111. In this area, soils are marly and have lower

2 organic matter content than the peat soils found in the other four study sites. These soils typically

3 have lower P content when reported on a per-weight basis (Harris \& Hurt 1999). Gradients of

4 nutrient enrichment as a function of distance from canals have been reported over much greater

5 distances than those found in this study (Doren et al. 1997; Childers et al. 2003). For instance,

6 Childers et al. (2003) reports exponential increases in soil P up to $4 \mathrm{~km}$ from a canal in high

7 enrichment canals and less than $0.5 \mathrm{~km}$ in low enrichment canals including areas in the proximity

8 of our L29 site.

$9 \quad$ Increases in net primary production may result in changes in patterns of abundance and

10 species composition in higher trophic levels. However, both theoretical and empirical evidence

11 show that these responses may be varied and unpredictable (Power, 1992; Abrams, 1993), and

12 strongly dependent on food-web structure (Leibold \& Wilbur, 1992). In the Everglades, multiple

13 effects have been reported in response to anthropogenic P enrichment. Even at low

14 concentrations of TP, persistent phosphorus loading alters periphyton community composition,

15 and mats eventually collapse (Gaiser et al. 2005). In the plant community, stem density and/or

16 biomass of macrophytes may increase in response to persistent low-concentration P enrichment

17 (Daoust \& Childers, 2004; Gaiser et al. 2005). High levels of P-loading lead to the replacement

18 of both periphyton and macrophytes by monocultures of cattail Typha domingensis (Davis 1994,

19 Doren et al. 1997).

20 In our study, the abundance of all groups, including large predators, was positively

21 correlated to $\mathrm{P}$ enrichment levels. However, previous studies have reported both positive and

22 negative relationships between primary-consumer density and P levels. Increases in the

23 abundance and diversity of small fishes and macroinvertebrates have been reported along natural 
1 productivity gradients in marshes (Turner et al. 1999; Trexler et al. 2002). In response to

2 anthropogenic P enrichment, Turner et al. (1999) reported higher standing stocks (dry mass $\mathrm{m}^{-2}$ )

3 of small fish in P-enriched sites near canal inflows $(<3 \mathrm{~km})$, but no difference in invertebrate

4 standing stocks. Rader and Richardson (1994) reported greater densities and species richness of

5 both small fishes and invertebrates in P-enriched sites in the northern Everglades, but

6 comparable trophic structure. McCormick et al. (2004) documented both increases and

7 decreases in macroinvertebrate densities in enriched sites depending on the microhabitat

8 sampled, accompanied by large compositional changes and some functional changes. Gaiser et

9 al. (2005) reported complex responses in fish biomass that were dependent on dosing level and

10 time since dosing was initiated.

11 Our data showed that sharp increases in the density of aquatic organisms within $5 \mathrm{~m}$ from

12 canals were more prevalent in the dry season. This seasonal pattern suggests that canals act as

13 dry-down refugia for both large and small aquatic organisms. These dry-season effects were

14 detected even in marshes with long hydroperiods and that did not dry in the year of our study.

15 Marsh animals may be altering habitat use to move toward canals either in anticipation of

16 dropping water levels or in response to other physiological requirements (i.e., mating, foraging)

17 or stresses (i.e., decreased water quality). Previous research has reported a similar accumulation

18 of predatory fishes in alligator holes in years when marsh levels drop below $30 \mathrm{~cm}$ (Kushlan,

19 1974; Nelson \& Loftus, 1996; Trexler et al. 2002). Even in long-hydroperiod marshes that rarely

20 dry and where direct mortality due to dry-down conditions is unlikely, predator densities

21 decrease significantly in the open marsh during the dry season, further suggesting movements

22 into deep-water refugia (Chick et al. 2004). Radiotelemetry data demonstrate that Florida gar

23 move long distances $(>10 \mathrm{~km})$ in response to drops in water level (J. Trexler, unpublished data). 
1 Genetic analyses indicate that spotted sunfish are more homogeneous in canals than in interior-

2 marsh alligator ponds, possibly from increased mixing resulting from dry-season colonization

3 from many sources and/or high dispersal within canals (McElroy et al. 2002).

$4 \quad$ Fluctuations of the hydrology of aquatic systems strongly affect fish and

5 macroinvertebrate populations (Snodgrass et al. 1996; Corti et al. 1997). The hydrologic pattern

6 of recurrent drought of Everglades marshes is a strong limiting factor on the abundance of

7 aquatic organisms living there (Loftus \& Eklund, 1994; Ruetz et al. 2005; Trexler et al. 2005),

8 particularly on long-lived (i.e., large) fishes (Chick et al. 2004). Standing stocks of fish are

9 relatively low compared to other wetlands (Turner et al. 1999). Disturbance from seasonal

10 drying and from more severe drought events are known to cause significant fish mortality

11 (Kushlan, 1974; Nelson \& Loftus, 1996). Access to dry-season refuges is thought to be a key

12 factor affecting survival and overall population dynamics (DeAngelis et al. 1997). Increased

13 water permanence provided by canals may lessen the limiting effect of hydrology on fish

14 populations, at least at the local scale.

15 Few compositional changes in the aquatic communities sampled were detected as a

16 function of distance from canals. Most of the community variation was detected among canal

17 sites, and we consider this variation to reflect regional differences resulting from gradients in

18 hydroperiod and productivity, as well as water management practices (Chick et al. 2004). We

19 detected some compositional changes in the predatory fish community, and we suspect they

20 indicate differences among large fishes in either their preference or ability to find suitable habitat

21 in canals. Canals provide larger and deeper open-water habitats than those found naturally in the

22 ecosystem (Gunderson \& Loftus, 1993), but habitat quality could be low. Most of the open water

23 habitat of South Florida canals appears to be underutilized by fishes, and the lack of structural 
1 complexity can diminish recruitment (Annett, 1998). On the other hand, the lack of habitat

2 complexity may increase the foraging efficiency of predators (Crowder \& Cooper, 1982; Savino

$3 \&$ Stein, 1989), although large numbers of prey are typically absent from the open-water areas of

4 canals (Fury et al. 1996) except in dry seasons when marshes are completely dried.

5 If high rates of predation are occurring close to canals, the effect appears

6 overcompensated by stimulation of increased secondary productivity by nutrient enrichment and

7 immigration toward areas adjacent to canals in the dry season. Theory predicts predator effects

8 to be relatively weak in frequently-disturbed habitats (Menge \& Sutherland, 1987). Kushlan

9 (1976) suggested that Everglades fish predators have an effect on prey densities only when the

10 frequency of dry-down events is low. Trexler et al. (2005) showed that predator regulation may

11 occur in regions of the ecosystem where the frequency of dry-down is very low (every 10-20

12 years), such as WCA3A. If canals decrease the frequency of disturbance, at least locally,

13 stronger predator effects may be expected, which were not detected in our study. However, lack

14 of an apparent predatory effect at high predator densities close to canals does not negate the role

15 of predation because sampling data only indicate net patterns in population dynamics.

16 Off-road vehicles (ORV) are known to negatively affect vegetation and soils in

17 Everglades habitats (NPS, 2000; Welch et al. 2002). ORV use, including the use of airboats, has

18 resulted in alterations of flow patterns, soil displacement, and plant community compositional

19 changes. In our study, disturbance from airboat trails had some effects on densities of aquatic

20 organisms, although effects were limited to short distances from canals. In cases where

21 differences were detected, greater numbers of fishes and macroinvertebrates were detected in

22 airboat trails than in undisturbed marshes. We suspect these effects relate to variation in habitat

23 quality. Although we did not detect large differences in stem density, differences in plant 
1 community structure (higher numbers of water lilies such as Nymphaea spp at $5 \mathrm{~m}$ from canals)

2 and lower periphyton volumes made trails more open habitats that may be preferred by large fish

3 species. Radiotelemetry surveys suggest that large fishes disperse through marshes using trails

4 (Trexler et al. unpublished data). Trails had highly disturbed sediments, and were slightly deeper

5 than undisturbed marshes. This suspension of floc could also make them preferred foraging

6 grounds for detritivores.

7 This study has important implications for efforts to assess the impact of canals in the

8 Everglades. Our results indicate that canal effects are complex and not easily ascertained by net

9 patterns of population density. Canals affect immigration, resource availability, and predatory

10 consumption simultaneously in complex patterns. The net effect of canals appears to be limited

11 to their immediate vicinity if they are not delivering nutrient-enriched water consistently over

12 time. However, this may mask general effects of canals if their impact as refuges for large

13 predatory fishes is spread throughout the ecosystem by relatively long-distance dispersal in the

14 wet season. Further research into movement patterns of these fishes, along with experimental

15 analysis of their impacts, is required to further elucidate results from this study.

\section{Acknowledgements}

18 This project was supported by Cooperative Agreement H5281-02-A0C1 between Florida

19 International University and Everglades National Park and the National Science Foundation

20 through funding to the Florida Coastal Everglades (FCE) Long-term Ecological Research

21 program (grant no. 9910514). We thank B. Shamblin, R. Urgelles, E. Grumbach, and A.

22 Gonzalez for their field and laboratory assistance. We thank S.E. Liston, K.J. Dunker, and two

23 reviewers, whose comments greatly improved this manuscript. 


\section{References}

2 Abrams, P. A., 1993. Effects of increased productivity on the abundances of trophic levels. American Naturalist 141: 351-371.

4 Annett, C. A., 1998. Hunting behavior of Florida largemouth bass, Micropterus salmoides floridanus, in a channelized river. Environmental Biology of Fishes 53: 75-87.

6 Bedford, B. L., \& E. M. Preston, eds. 1998. Cumulative effects on landscape system of wetlands: scientific status, prospects and regulatory perspectives. Environmental

9 Brönmark, C. \& L-A. Hansson, 2002. Environmental issues in lakes and ponds: current state and perspectives. Environmental Conservation 29: 290-306.

11 Clarke, K. R. \& R. M. Warwick, 2001. Changes in marine communities: an approach to statistical analyses and interpretation, $2^{\text {nd }}$ edition. National Environmental Research Council, Plymouth Marine Laboratory, Plymouth, UK.

14 Comprehensive Everglades Restoration Plan (CERP), 1999. U.S. Army Corps of Engineers and

17 Chick, J. H., S. Coyne, \& J. C. Trexler, 1999. Effectiveness of airboat electrofishing for sampling fishes in shallow vegetated habitats. North American Journal of Fisheries Management 19: 957-967.

Chick, J. H., C. R. Ruetz \& J. C. Trexler, 2004. Spatial scale and abundance patterns of large fish communities in freshwater marshes of the Florida Everglades. Wetlands 24: 652-664.

22 Childers, D. L., R. F. Doren, R. Jones, G. B. Noe, M. Rugge \& L. J. Scinto, 2003. Decadal 
changes in vegetation and soil phosphorus pattern across the Everglades landscape. Journal of Environmental Quality 32: 344-362.

3 Corti, D., S. L. Kohler \& R. E. Sparks, 1997. Effects of hydroperiod and predation on a

$4 \quad$ Mississippi River floodplain invertebrate community. Oecologia 109: 154-165.

5 Crowder, L. B. \& W. E. Cooper, 1982. Habitat structural complexity and the interaction between $6 \quad$ bluegill and their prey. Ecology 63: 1802-1813.

7 Daoust, R. J. \& D. L. Childers, 2004. Ecological effects of low-level phosphorus additions on two plant communities in a neotropical freshwater wetland ecosystem. Oecologia 141: 672-686.

Davis, S. M., 1994. Phosphorus inputs and vegetation sensitivity in the Everglades. In Davis, S. M. \& J. C. Ogden (eds), Everglades: the System and its Restoration. St. Lucie Press, Delray Beach FL: 357-378.

Davis, S. M., L. H. Gunderson, W. A. Park, J. R. Richardson \& J. E. Mattson, 1994. Landscape dimension, composition, and function in a changing Everglades ecosystem. In Davis, S. M. \& J.C. Ogden (eds), Everglades: the System and its Restoration. St. Lucie Press, Delray Beach FL: 419-444.

DeAngelis, D. L., W. F. Loftus, J. C. Trexler \& R. E. Ulanowicz, 1997. Modeling fish dynamics in a hydrologically pulsed ecosystem. Journal of Aquatic Ecosystem Stress and Recovery 6: 1-13.

Doren, R. F., T. V. Armentano, L. D. Whiteaker \& R. D. Jones, 1997. Marsh vegetation patterns and soil phosphorus gradients in the Everglades ecosystem. Aquatic Botany 56: 145-163.

Dynesius, M. \& C. Nilsson, 1994. Fragmentation and flow regulation of river systems in the northern third of the world. Science 266: 753-762. 
1 Fourqurean, J. W., J. C. Zieman, \& G. V. N. Powell, 1992. Phosphorus limitation of primary

2 production in Florida Bay: evidence from the C:N:P ratios of the dominant seagrass

$3 \quad$ Thalassia testudinum. Limnology and Oceanography 37: 162-171.

4 Frederick, P. C. \& M. G. Spalding, 1994. Factors affecting reproductive success of wading birds

5 (Ciconiiformes) in the Everglades ecosystem. In Davis, S. M. \& J. C. Ogden

6 (eds), Everglades: the System and its Restoration. St. Lucie Press, Delray Beach FL: 659-

$7 \quad 691$.

8 Fury, J. R., J. D. Wiikert, J. Cimbaro \& F. Morello, 1996. Everglades fisheries investigations

9 Project F56. Florida Fish and Wildlife Conservation Commission Report, Vero Beach

$10 \quad$ FL.

11 Gaiser, E. E., J. C. Trexler, J. H. Richards, D. L. Childers, D. Lee, A. L. Edwards, L. J. Scinto,

12 K. Jayachandran. G. B. Noe \& R. D. Jones, 2005. Cascading ecological effects of low-

13 level phosphorus enrichment in the Florida Everglades. Journal of Environmental Quality

$14 \quad 34: 1-8$.

15 Gergel, S. E., 2002. Assessing cumulative impacts of levees and dams on floodplain ponds: a

16 neutral-terrain model approach. Ecological Applications 12: 1740-1754.

17 Gunderson, L. H. \& W. F. Loftus, 1993. The Everglades. In Martin, W.H., S.G. Boyce \& A.C.

18 Echternacht (eds), Biodiversity of the Southeastern United States: Lowland Terrestrial

19 Communities. John Wiley \& Sons, New York NY: 199-255.

20 Harris, W. \& W. Hurt. 1999. Introduction to soils of subtropical Florida. In Reddy, K. R. et al.

21 (eds), Phosphorus Biogeochemistry in Subtropical Ecosystems. Lewis, New York, NY:

$22 \quad 143-170$.

23 Jordan, F., S. Coyne \& J. C. Trexler, 1997. Sampling fishes in vegetated habitats effects of 
habitat structure on sampling characteristics of the $1-\mathrm{m}^{2}$ throw trap. Transactions of the American Fisheries Society 126: 1012-1020.

King, R. S., C. J. Richardson, D. L. Urban, \& E. A. Romanowicz, 2004. Spatial dependency of

11 Leibold, M. A., J. M. Chase, J. B. Shurin \& A. L. Downing, 1997. Species turnover and the vegetation-environment linkages in an anthropogenically influenced wetland ecosystem. Ecosystems 7: 75-97.

Kushlan, J. A., 1974. Observations on the role of the American alligator (Alligator mississippiensis) in the southern Florida wetlands. Copeia 1974: 993-996.

Kushlan, J. A., 1976. Environmental stability \& fish community diversity. Ecology 57: 821-825.

Kushlan, J. A., 1981. Sampling characteristics of enclosure fish traps. Transactions of the American Fisheries Society 110: 557-662. regulation of trophic structure. Annual Review of Ecology and Systematics 28: 467-494.

Light, S. S. \& J. W. Dineen, 1994. Water control in the Everglades: a historical perspective. In Davis, S. M. \& J. C. Ogden (eds), Everglades: the System and its Restoration. St. Lucie Press, Delray Beach FL: 47-84.

Littell, R. C., G. A. Milliken, W. W. Stroup \& R. D. Wolfinger, 1996. SAS® System for Mixed Models. SAS Institute, Cary NC.

Loftus, W. F. \& J. A. Kushlan, 1987. Freshwater fishes of southern Florida. Bulletin of the Florida State Museum - Biological Sciences 31: 147-344.

Loftus, W. F. \& A. M. Eklund, 1994. Long-term dynamics of an Everglades fish community. In Davis, S. M. \& J.C. Ogden (eds.), Everglades: the System and its Restoration. St. Lucie Press, Delray Beach FL: 461-483.

McCormick, P. V., R. E. Shuford \& P. S. Rawlik, 2004. Changes in macroinvertebrate 
community structure along a phosphorus gradient in the Florida Everglades. Hydrobiologia 529: 113-132.

McElroy, T. C., L. L. Kandl, J. Garcia \& J. C. Trexler, 2002. Extinction-colonization dynamics structure genetic variation of spotted sunfish (Lepomis punctatus) in the Florida Everglades. Molecular Ecology 12: 355-368.

Naiman, R. J. \& M. G. Turner, 2000. A future perspective on North America's freshwater ecosystems. Ecological Applications 10: 958-970.

Nelson, C. M. \& W. F. Loftus, 1996. Effects of high-water conditions on fish communities in Everglades alligator ponds. In Armentano, T.V. (ed), Proceedings of the 1996 Conference: Ecological Assessment of the 1994-1995 High Water Conditions in the Southern Everglades. Florida International University, Miami, FL, 22-23 August 1996: 89-101.

Noe, G. B., D. L. Childers \& R. D. Jones, 2001. Phosphorus biogeochemistry and the impact of phosphorus enrichment: why is the Everglades so unique? Ecosystems 4: 603-624.

Noe, G. B., D. L. Childers, A. L. Edwards, E. Gaiser, K. Jayachandran, D. Lee, J. Meeder, J. Richards, L. J. Scinto, J. C. Trexler \& R. D. Jones, 2002. Short-term changes in phosphorus storage in an oligotrophic Everglades wetland system receiving experimental nutrient enrichment. Biogeochemistry 59: 239-267.

NPS (National Park Service), 2000. Final recreational off-road vehicle management plan supplemental environmental impact statement. U.S. National Park Service, Big Cypress National Preserve, Ochopee, FL. (http://www.nps.gov/bicy/Bicy-018.htm)

NRC (National Research Council), 1992. Restoration of aquatic ecosystems: science, technology, and public policy. National Academy Press, Washington DC. 
1 Polis, G. A. \& D. R. Strong, 1996. Food web complexity and community dynamics. American $2 \quad$ Naturalist 147: 813-846.

3 Power, M. E. Top-down and bottom-up forces in food webs: do plants have primacy. Ecology $4 \quad 73: 733-746$.

5 Power, M. E., A. Sun, G. Parker, W. E. Dietrich, \& J. T. Wootton, 1995. Hydraulic food-chain 6 models. BioScience 45: 159-168.

7 Pringle, C. M., 2001. Hydrologic connectivity and the management of biological reserves: a 8 global perspective. Ecological Applications 11: 981-998.

9 Rader, R. B. \& C.J. Richardson, 1994. Response of macroinvertebrates and small fish to

11 Rosenberg, D. M, P. McCully \& C. M. Pringle, 2000. Global-scale environmental effects of 12 hydrological alterations; introduction. BioScience 50: 746-751.

13 Ruetz, C. R., J. C. Trexler, F. Jordan, W. F. Loftus \& S. A. Perry, 2005. Population dynamics of 14 wetland fishes: spatiotemporal patterns shaped by hydrological disturbance? Journal of Animal Ecology 74:322-332.

16 Sanchez-Carrillo, S. \& M. Alvarez-Cobelas, 2001. Nutrient dynamics and eutrophication patterns in a semi-arid wetland: the effects of fluctuating hydrology. Water, Air and Soil

19 Savino, J.F. \& R. A. Stein, 1989. Behavioral interactions between fish predators and their prey:

21 Schneider, D. W. \& T. M. Frost, 1996. Habitat duration and community structure in temporary ponds. Journal of the North American Benthological Society 15: 64-86.

23 Skelly, D. K., E. E. Werner, \& S. A. Cortwright, 1999. Long-term distributional dynamics of a 
Michigan amphibian assemblage. Ecology 80: 2326-2337.

2 Trexler, J. C., W. F. Loftus, C. F. Jordan, J. H. Chick, K. L. Kandl, T. C. McElroy, \& O. L. Bass, 2002. Ecological scale and its implications for freshwater fishes in the Florida Everglades. In Porter, J.W. \& K. G. Porter (eds), The Everglades, Florida Bay, and Coral Reefs of the Florida Keys: An Ecosystem Sourcebook. CRC Press, Boca Raton FL: 153181.

Trexler, J. C., W. F. Loftus, F. Jordan, J. Lorenz, J. H.Chick \& R. M. Kobza, 2001. Empirical assessment of fish introductions in a subtropical wetland: an evaluation of contrasting views. Biological Invasions 2:265-277.

Trexler, J. C., W. F. Loftus \& S. Perry, 2005. Hydrological limitation of Everglades fish communities by a twenty-five year intervention study. Oecologia Online first: DOI: 10.1007/s00442-005-0094-4

Turner, M. G., S. R. Carpenter, E. J. Gustafson, R. J. Naiman \& S. M. Pearson, 1998. Land use. In Mac, J. , P. A. Opler, P. Doran \& C. Haecker (eds), Status and Trends of our Nation's Biological Resources, Volume 1. National Biological Service, Washington DC: 37-61.

Turner, A. M., J. C. Trexler, F. Jordan, S. J. Slack, P. Geddes, J. Chick \& W. F. Loftus, 1999. Targeting ecosystem features for conservation: standing crops in the Florida Everglades. Conservation Biology 13: 898-911.

Welch, R., M. Madden \& B. Doren, 2002. Maps and GIS databases for environmental studies of the Everglades. In Porter, J.W., \& K. G. Porter (eds), The Everglades, Florida Bay and Coral Reefs of the Florida Keys, an Ecosystem Sourcebook. CRC Press, Boca Raton FL: 259-279.

Wellborn, G. A., D. K. Skelly \& E. E. Werner, 1996. Mechanisms creating community structure 
across a freshwater habitat gradient. Annual Review of Ecology and Systematics 27: 337363.

3 Wilbur, H. M., 1980. Complex life cycles. Annual Review of Ecology and Systematics 11: 6793. 
Table 1. Summary of results of nested ANOVAs and ANCOVAs testing the effect of season, canal, distance, disturbance, and relevant covariates on small fish and macroinvertebrate densities and large fish CPUE and testing effect of canal, distance, and disturbance on total phosphorus concentration in the floc layer.

\begin{tabular}{|c|c|c|c|c|c|c|c|c|c|c|c|c|}
\hline \multirow[b]{2}{*}{ Source of Variation } & \multicolumn{3}{|c|}{ Small Fish } & \multicolumn{3}{|c|}{ Macroinvertebrate } & \multicolumn{3}{|c|}{ Large Fish } & \multicolumn{3}{|c|}{ Floc Total Phosphorus } \\
\hline & $d f$ & $F$ & $p$ & $d f$ & $F$ & $p$ & $d f$ & $F$ & $p$ & $d f$ & $F$ & $p$ \\
\hline Season & 1,85 & 5.7 & 0.0188 & 1,89 & 76.9 & 0.0001 & 1,41 & 274.1 & 0.0001 & & & \\
\hline Canal & 4,103 & 54.6 & 0.0001 & 4,107 & 19.2 & 0.0001 & 4,48 & 7.4 & 0.0001 & 4,116 & 31.1 & 0.0001 \\
\hline Distance (Canal) & 20,92 & 9.9 & 0.0001 & 20,96 & 14.0 & 0.0001 & 19,46 & 15.5 & 0.0001 & 17,116 & 26.9 & 0.0001 \\
\hline Disturbance (Distance (Canal)) & 20,91 & 5.8 & 0.0001 & 20,95 & 7.0 & 0.0001 & 20,45 & 3.5 & 0.0003 & 17,116 & 10.2 & 0.0001 \\
\hline Season x Canal & 4,87 & 10.5 & 0.0001 & 4,91 & 4.9 & 0.0013 & 4,41 & 5.4 & 0.0014 & & & \\
\hline Season x Distance (Canal) & 19,84 & 2.8 & 0.0007 & 19,88 & 3.1 & 0.0002 & 15,41 & 9.2 & 0.0001 & & & \\
\hline Season x Disturbance (Distance (Canal)) & 17,84 & 1.8 & 0.0399 & 17,89 & 3.1 & 0.0003 & 17,41 & 1.7 & 0.0935 & & & \\
\hline Plant density & 1,167 & 11.1 & 0.001 & 1,167 & 42.6 & 0.0001 & & & & & & \\
\hline Periphyton volume & 1,167 & 8.0 & 0.0054 & 1,167 & 2.25 & 0.1356 & & & & & & \\
\hline
\end{tabular}




\section{FIGURE LEGENDS}

Fig. 1. Map showing the main canals (black lines) throughout the southern and central Everglades ecosystem and urban areas to the east. Labels indicate the 5 canals included in this study: L28, L29, L67, and I75 canals in Water Conservation Area 3A (WCA3A) and C111 canal southeastern region of Everglades National Park (ENP). Sampling took place in two transects perpendicular to each canal; one that followed an airboat trail and a parallel transect in undisturbed marsh (approximately $350 \mathrm{~m}$ away). Circles in diagram indicate distances sampled away from canals: $5 \mathrm{~m}, 100 \mathrm{~m}, 500 \mathrm{~m}, 1000 \mathrm{~m}$ (filled symbols), and an average of $7500 \mathrm{~m}$ for the inner most sites (open symbols and sampled only in the undisturbed marsh).

Fig. 2. (a) Small fish $\left(\mathrm{SL}<8 \mathrm{~cm}\right.$ ) density (number $\mathrm{m}^{-}{ }^{2}$ ), (b) macroinvertebrate density (number $\mathrm{m}^{-2}$ ), and (c) large fish (SL > $8 \mathrm{~cm}$ ) CPUE (number 5 min. electrofishing bout ${ }^{-1}$ ) shown as a function of distance from a canal for the 5 canal sites (C111, L28, L29, L67 and I75) and shown separately by season. Data are means \pm 1 SE.

Fig. 3. Total phosphorus (TP) concentration $\left(\mu \mathrm{g} \mathrm{g}^{-1}\right)$ as a function of distance from a canal for the 5 canal study sites (C111, L28, L29, L67 and I75). Data are means \pm 1 SE.

Fig. 4. Estimates of abundance averaged across sampling seasons (Log-transformed) plotted as a function of floc TP concentration. Separate least-squares regression functions were fitted to large fish CPUE (solid line), small fish density (dashed line), and macroinvertebrate density (dotted line). 
Fig. 5. Two-dimensional non-metric MDS ordination of (a) small fish and (b) macroinvertebrate densities, and of (c) large fish CPUE based on $\sqrt{ }$-transformed values and Bray-Curtis similarities, and averaged across seasons. Symbols designate the 5 canal study sites, whereas shading designates distances from canals. Circles surrounding symbols indicate the main canal and distance groupings. 
Figure 1.

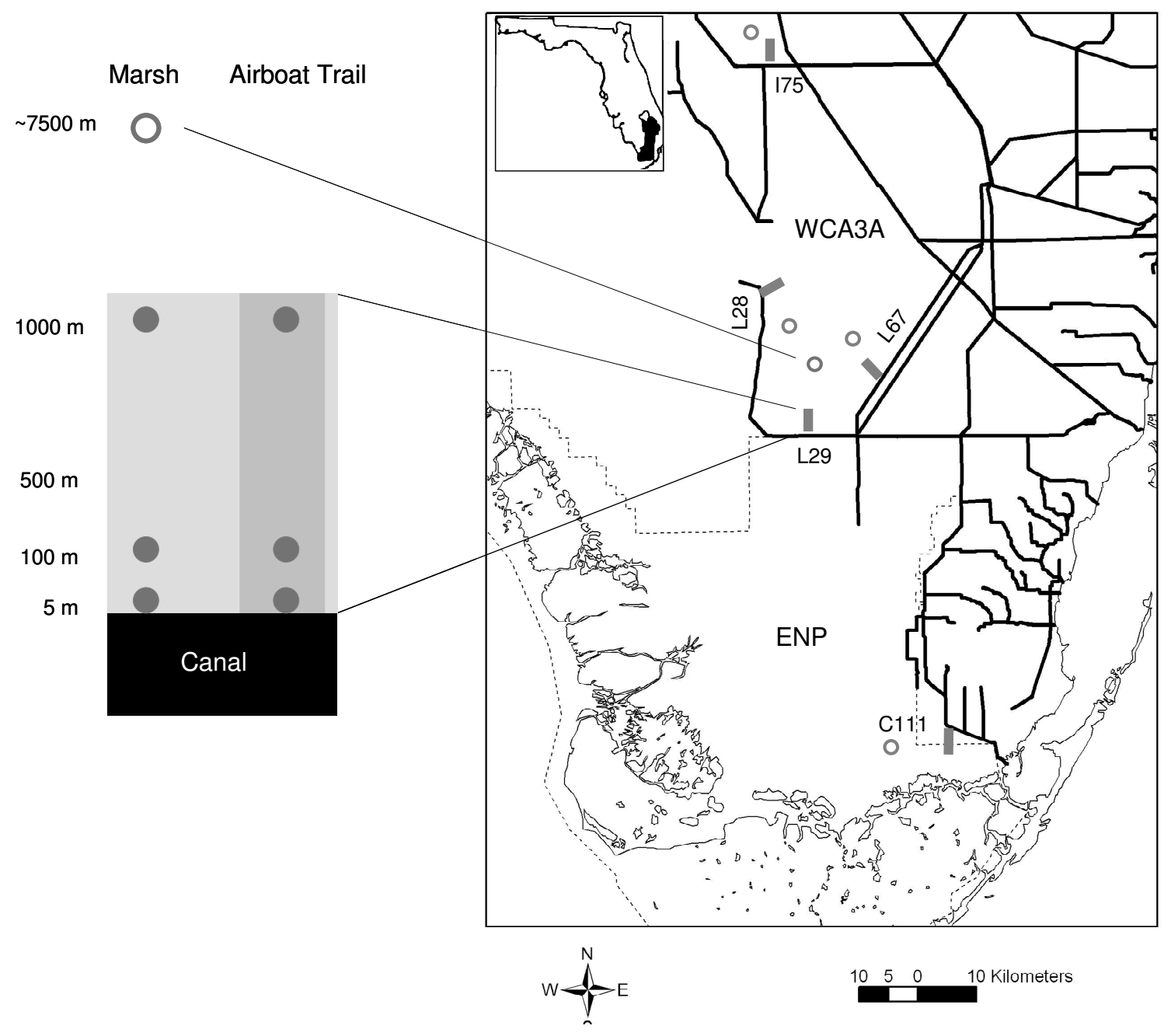


Figure 2.

Wet Season Dry Season

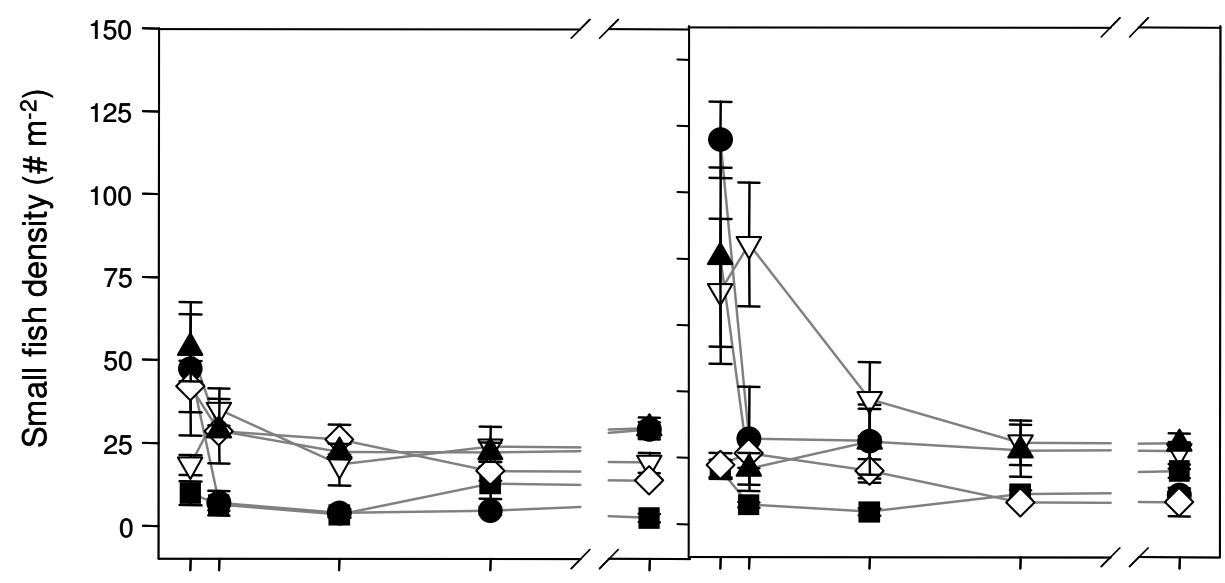

Canals:

- C111

$\nabla \quad$ L28

- L29

$\diamond \quad$ L67

- 175
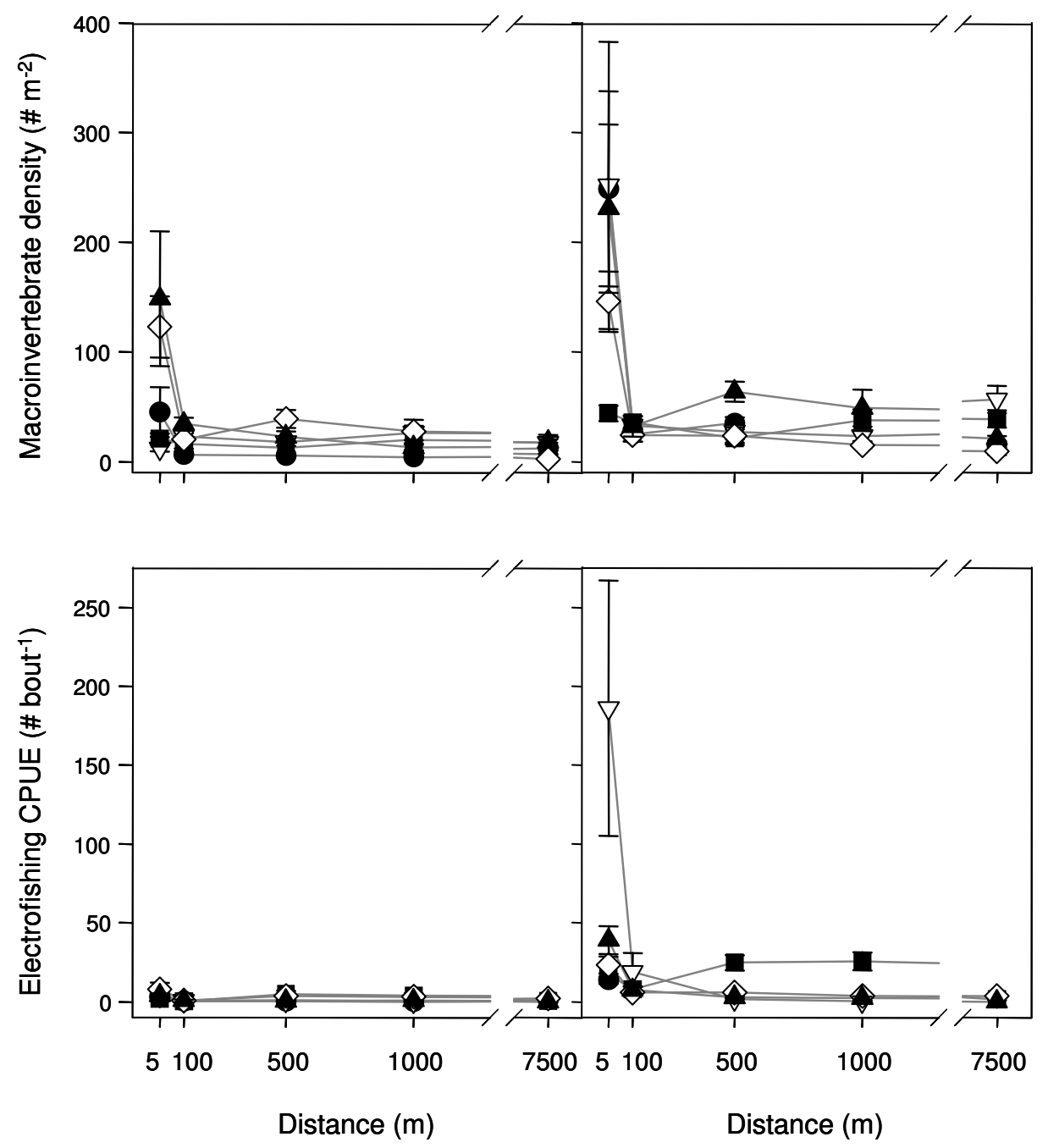
Figure 3.

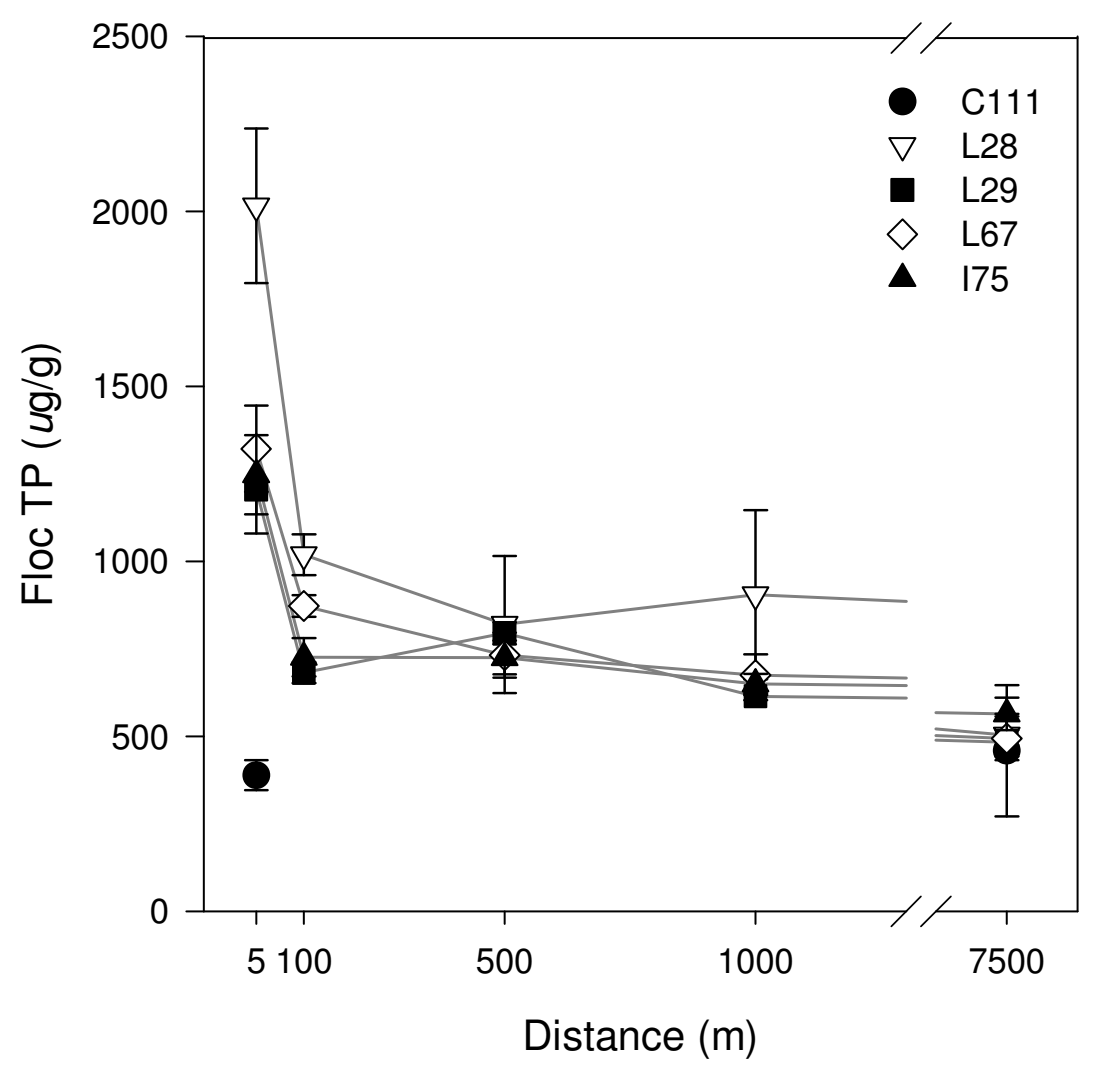


Figure 4.

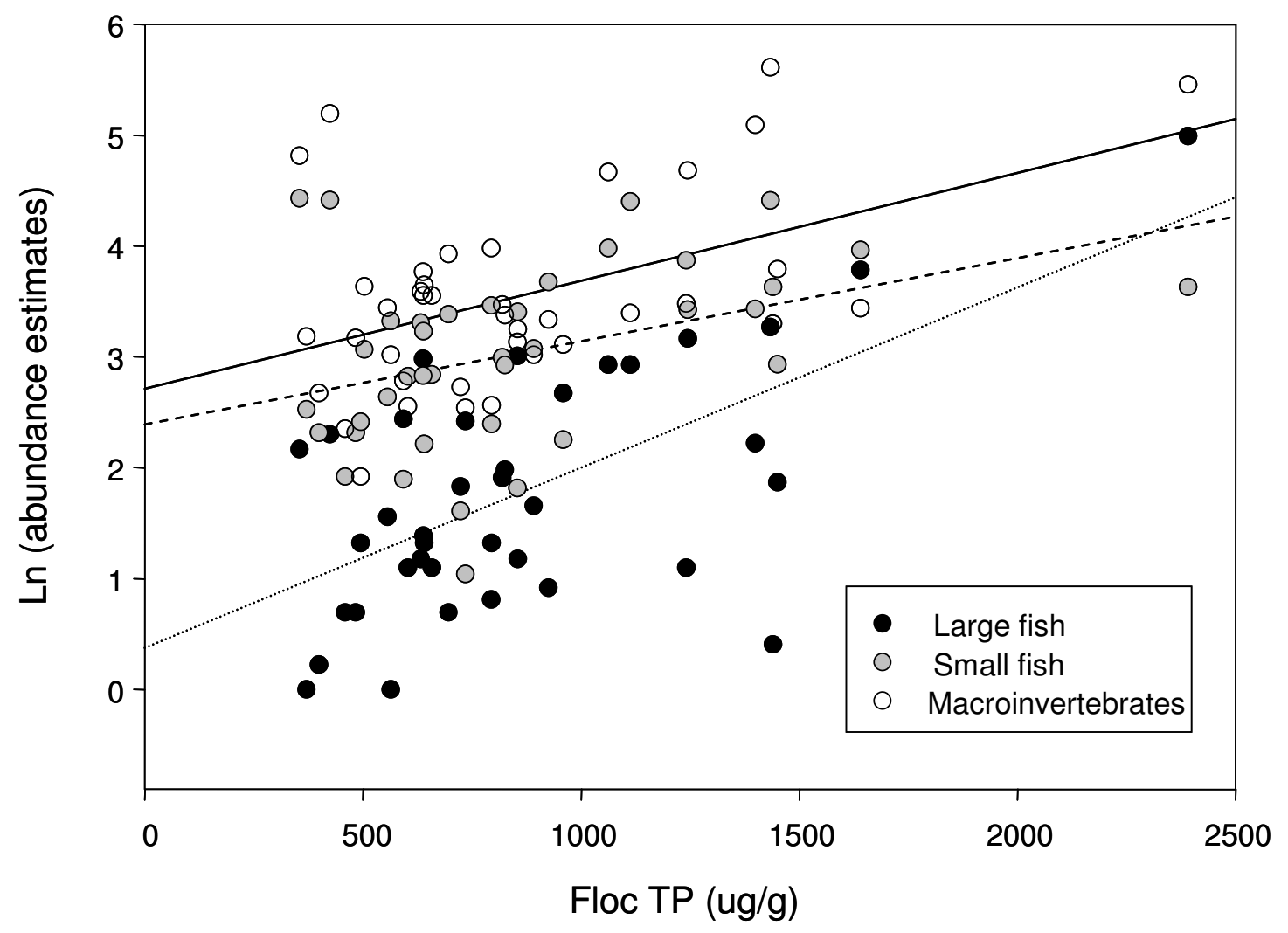


Figure 5.

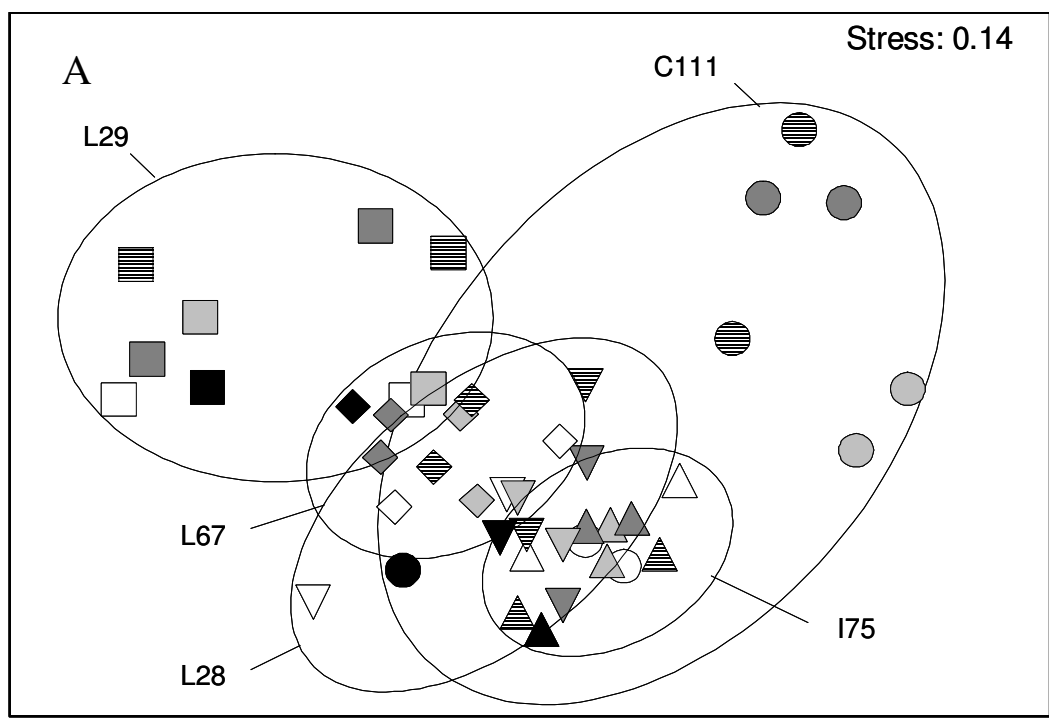

\begin{tabular}{|lllr|}
\hline Canals: & \multicolumn{2}{c|}{ Distances: } \\
$\bigcirc$ & $\mathrm{C} 111$ & & $5 \mathrm{~m}$ \\
$\nabla$ & $\mathrm{L} 28$ & & $100 \mathrm{~m}$ \\
$\square$ & $\mathrm{L} 29$ & & $500 \mathrm{~m}$ \\
$\diamond$ & $\mathrm{L} 67$ & & $1000 \mathrm{~m}$ \\
$\triangle$ & $\mathrm{I} 75$ & & $7500 \mathrm{~m}$ \\
\hline
\end{tabular}
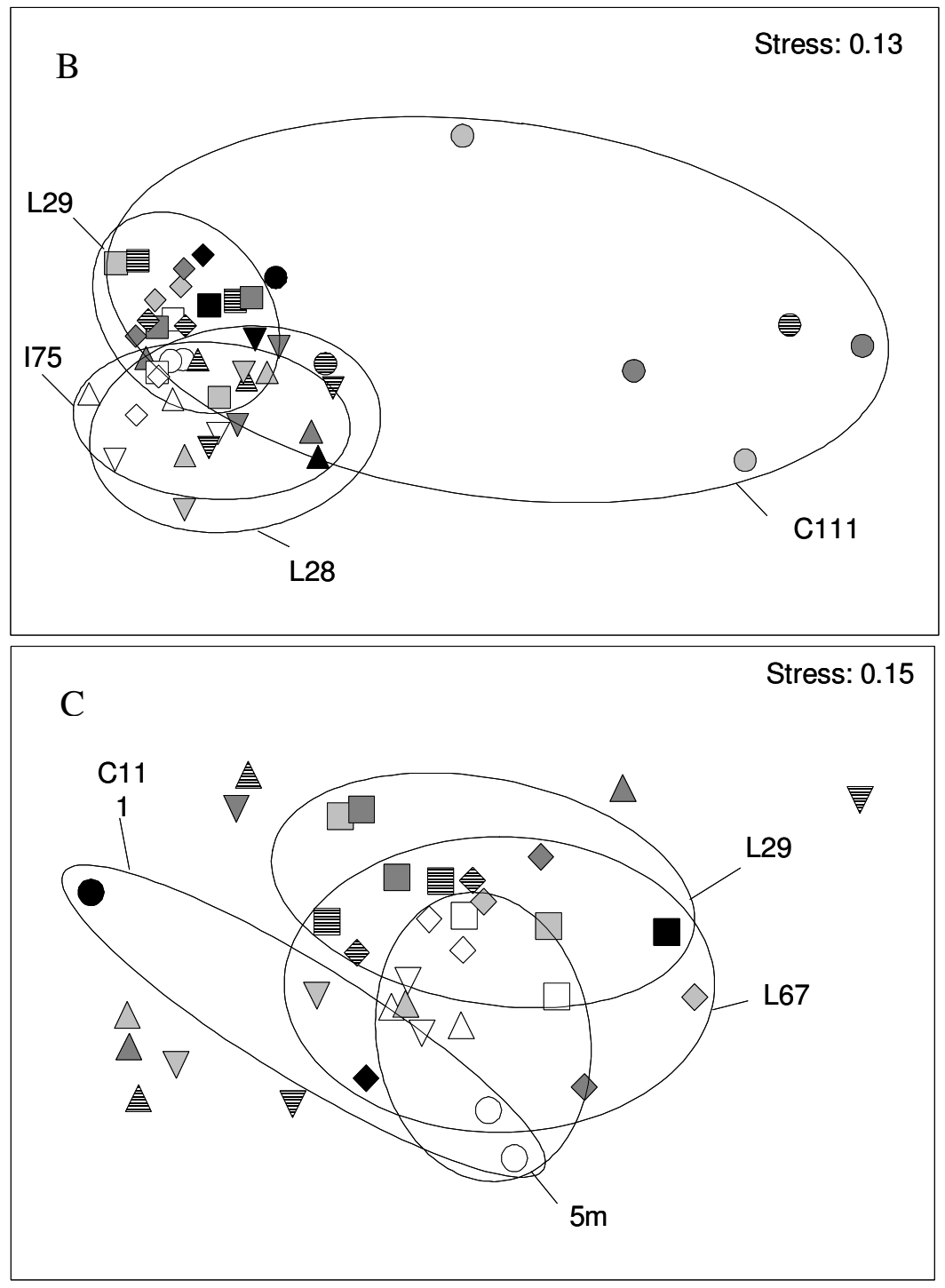
Electronic Appendix 1. Total number of organisms caught in electrofishing and throw trap samples shown separately by taxon.

\begin{tabular}{|c|c|c|c|c|c|}
\hline \multirow{2}{*}{$\begin{array}{l}\text { Large fishes }(>7 \mathrm{~cm} \mathrm{SL)} \\
\text { Lepomis gulosus }\end{array}$} & \multicolumn{3}{|c|}{ Small fishes $(<7 \mathrm{~cm} \mathrm{SL})$} & \multicolumn{2}{|c|}{ Macroinvertebrates (>5 $\mathrm{mm}$ size } \\
\hline & 585 & Heterandria formosa & 1858 & Palaemonetes paludosus ${ }^{\mathrm{d}}$ & 9723 \\
\hline Micropterus salmoides & 292 & Lucania goodie & 1781 & Celithemis eponina $^{\mathrm{b}}$ & 580 \\
\hline Lepisosteus platyrhincus & 197 & Gambusia holbrooki & 1565 & Coenagrionidae & 287 \\
\hline Erymizon sucetta & 166 & Fundulus chrysotus & 318 & Planorbella duryi ${ }^{c}$ & 279 \\
\hline Lepomis macrochirus & 110 & Enneacanthus gloriousus & 317 & Brachymesia gravida ${ }^{\mathrm{b}}$ & 267 \\
\hline Lepomis microlophus & 106 & Lepomis marginatus & 160 & Pelocoris femoratus ${ }^{e}$ & 245 \\
\hline Lepomis punctatus & 69 & Poecilia latipinna & 145 & Procambarus fallax ${ }^{\mathrm{d}}$ & 202 \\
\hline Amia calva & 61 & Jordanella floridae & 138 & Libellula needhami ${ }^{\mathrm{b}}$ & 128 \\
\hline Esox americanus & 36 & Lepomis punctatus & 108 & Planorbella scalaris ${ }^{c}$ & 119 \\
\hline Cichlasoma urophthalmus a & 25 & Elassoma evergladei & 85 & Pachydiplax longipennis ${ }^{\mathrm{b}}$ & 115 \\
\hline Notemigonus crysoleucas & 13 & Fundulus confluentus & 40 & Belostoma sp. ${ }^{\mathrm{e}}$ & 81 \\
\hline Fundulus seminolis & 11 & Lepomis gulosus & 29 & Coleoptera & 47 \\
\hline Oreochromis aureus ${ }^{\mathrm{a}}$ & 11 & Erymizon sucetta & 27 & Pomacea paludosa ${ }^{c}$ & 41 \\
\hline Tilapia mariae ${ }^{\mathrm{a}}$ & 11 & Esox americanus & 15 & Epitheca stella ${ }^{b}$ & 41 \\
\hline Ameiurus nebulosus & 5 & Micropterus salmoides & 9 & Ephemeroptera & 39 \\
\hline Amerius natalis & 4 & Etheostoma fusiforme & 9 & Procambarus alleni $^{\mathrm{d}}$ & 39 \\
\hline
\end{tabular}




\begin{tabular}{|c|c|c|c|c|c|}
\hline Hoplosternum littorale ${ }^{\mathrm{a}}$ & 4 & Ameiurus natalis & 7 & Coryphaeschna ingens ${ }^{\mathrm{b}}$ & 36 \\
\hline Clarias batrachus $^{\text {a }}$ & 3 & Lepomis macrochirus & 6 & Sphaeriidae & 36 \\
\hline Macrognathus siamensis ${ }^{\text {a }}$ & 3 & Cyprinodon variegatus & 4 & Erythemis simplicollis ${ }^{\mathrm{b}}$ & 35 \\
\hline Cichla ocellaris ${ }^{\text {a }}$ & 3 & Noturus gyrinus & 3 & Physella sp. ${ }^{\mathrm{c}}$ & 29 \\
\hline Esox niger & 2 & Aphredoderus sayanus & 3 & Melanoides tuberculata ${ }^{c}$ & 21 \\
\hline \multirow[t]{12}{*}{ Fundulus confluentus } & 1 & Cichlasoma urophthalmus $^{\mathrm{a}}$ & 2 & Marissa cornuaurietus ${ }^{\text {a, c }}$ & 11 \\
\hline & & Belonesox belizanus ${ }^{\mathrm{a}}$ & 2 & Hirudinea & 8 \\
\hline & & Labidesthes sicculus & 1 & Pseduosuccinea columella ${ }^{\mathrm{c}}$ & 7 \\
\hline & & Esox niger & 1 & Oligochaeta & 6 \\
\hline & & Lepomis microlophus & 1 & Perithemis tenera $^{\mathrm{b}}$ & 5 \\
\hline & & Pomoxis nigromaculatus & 1 & Stratiomydae & 5 \\
\hline & & Cichlasoma bimaculatum $^{\mathrm{a}}$ & 1 & Corixidae $^{\mathrm{e}}$ & 3 \\
\hline & & & & Pomacea bridgesi ${ }^{\mathrm{a}, \mathrm{c}}$ & 3 \\
\hline & & & & Planorbella trivolis ${ }^{\mathrm{c}}$ & 3 \\
\hline & & & & Arigomphus pallidus ${ }^{\mathrm{b}}$ & 2 \\
\hline & & & & Epitheca princeps regina ${ }^{\mathrm{b}}$ & 2 \\
\hline & & & & Taphromysis lousianae $\mathrm{f}^{\mathrm{f}}$ & 2 \\
\hline
\end{tabular}




\begin{tabular}{|c|c|c|c|c|}
\hline & & & Aphylla williamsoni $^{\mathrm{b}}$ & 1 \\
\hline & & & Littoridinops monroensis $^{\mathrm{c}}$ & 1 \\
\hline & & & Tabanidae & 1 \\
\hline Total taxa & 22 & 28 & & 36 \\
\hline Total individuals & 1718 & 6636 & & 12450 \\
\hline
\end{tabular}

${ }^{\text {a }}$ Non-indigenous species

${ }^{\mathrm{b}}$ Odonata larvae, ${ }^{\mathrm{c}}$ Gastropoda, ${ }^{\mathrm{d}}$ Decapoda, ${ }^{\mathrm{e}}$ Hemiptera, ${ }^{\mathrm{f}}$ Mysidacea 